\title{
Along-axis gravity gradients at mid-ocean ridges: Implications for mantle flow and axial morphology
}

\author{
Xuejin Wang \\ James R. Cochran \\ Lamont-Doherty Earth Observatory of Columbia University, Palisades, New York 10964
}

\begin{abstract}
Along-axis gradients in mantle Bouguer anomalies (MBAs) were calculated for detailed gravity surveys at the Southwest, Central, and Southeast Indian ridges with halfspreading rates of $0.9,2.3$, and $3.1 \mathrm{~cm} / \mathrm{yr}$, respectively. MBA gradients at the very slow spreading Southwest Indian Ridge are $0.4-0.7 \mathrm{mgal} / \mathrm{km}$, similar to the gradients found at the slow-spreading Mid-Atlantic Ridge, whereas gradients at the Central Indian and Southeast Indian ridges are $0.2-0.35 \mathrm{mgal} / \mathrm{km}$. The results of this study, when combined with other published data, show that axial MBA gradients at ridge segments with an axial high are about $0.1 \mathrm{mgal} / \mathrm{km}$, independent of spreading rate. Gradients at segments with a median valley are higher and generally decrease with increasing spreading rate. The spreading-rate-independent MBA gradient at ridge segments with an axial high represents the mantle gravity signal due to the focusing of upwelling within segments. The larger gravity gradients at segments with an axial valley result from the superposition of intrasegment variations in crustal thickness on this mantle signal. The consistent relation between along-axis MBA gradient and across-axis axial morphology suggests that the axial morphology is related to the efficiency of along-axis transport of melt.
\end{abstract}

\section{INTRODUCTION}

Ridge-axis morphology and dynamics vary dramatically with spreading rate. Slow-spreading ridges are typically associated with a median valley and commonly exhibit circular mantle Bouguer gravity anomaly (MBA) lows ("bull's-eyes") over each spreading segment (Neumann and Forsyth, 1993; Lin et al., 1990) along with relatively large along-axis MBA gradients (Lin and Phipps Morgan, 1992). This characteristic pattern has been interpreted in terms of crustal-thickness variations - thicker crust beneath the middle of the segment and thinner crust toward the distal ends (Lin et al., 1990). Thus, the structure of the mantle upwelling appears to be threedimensional (plumelike) beneath slow-spreading ridges. In contrast, fast-spreading ridges display an axial high and have been reported to lack both the bull's-eye MBA pattern and the significant alongaxis MBA gradients observed at slow-spreading ridges (Lin and Phipps Morgan, 1992; Madsen et al., 1990). An inference drawn from these observations and from theoretical modeling is that mantle upwelling beneath fast-spreading ridges is two-dimensional (sheetlike) (Lin and Phipps Morgan, 1992; Parmentier and Phipps Morgan, 1990). In this paper, we analyze gravity data from geophysical surveys at the Southwest Indian, Central Indian, and Southeast Indian ridges with half-spreading rates of $0.9,2.3$, and $3.1 \mathrm{~cm} /$ yr, respectively. These data are combined with other published gravity data to clearly define the relations among MBA gradients, spreading rates, and axial morphology and to examine the implications for mantle flow and the formation of sea-floor morphology.

\section{DATA}

SeaBeam swath-bathymetry and gravity surveys were conducted by the Institut de Physique du Globe de Strasbourg on each of the three limbs of the Indian Ocean Ridge system at a distance of 400-500 km from the Rodriguez triple junction (Munschy, 1987) (Fig. 1). Mantle Bouguer anomalies were calculated by subtracting the gravity effects of the water-crust and crust-mantle interfaces from free-air gravity anomalies, assuming the density of the water, crust, and mantle to be $1030 \mathrm{~kg} / \mathrm{m}^{3}, 2730 \mathrm{~kg} / \mathrm{m}^{3}$, and $3300 \mathrm{~kg} / \mathrm{m}^{3}$, respectively, and a constant crustal thickness of $6 \mathrm{~km}$. In all three regions, roughly circular MBA lows are found over along-axis bathymetric highs (Fig. 2). Individual MBA lows correspond in extent to second-order ridge segments; the most negative axial MBA values are over the shallowest section of the axis in each segment. This is the general pattern observed at slow-spreading ridges and has been cited as evidence for focused upwelling beneath slow-spreading ridge axes (Lin et al., 1990).

\section{AXIAL MBA GRADIENTS}

Following Lin and Phipps Morgan's (1992) definition, we calculated along-axis half-segment MBA gradients for the three areas.

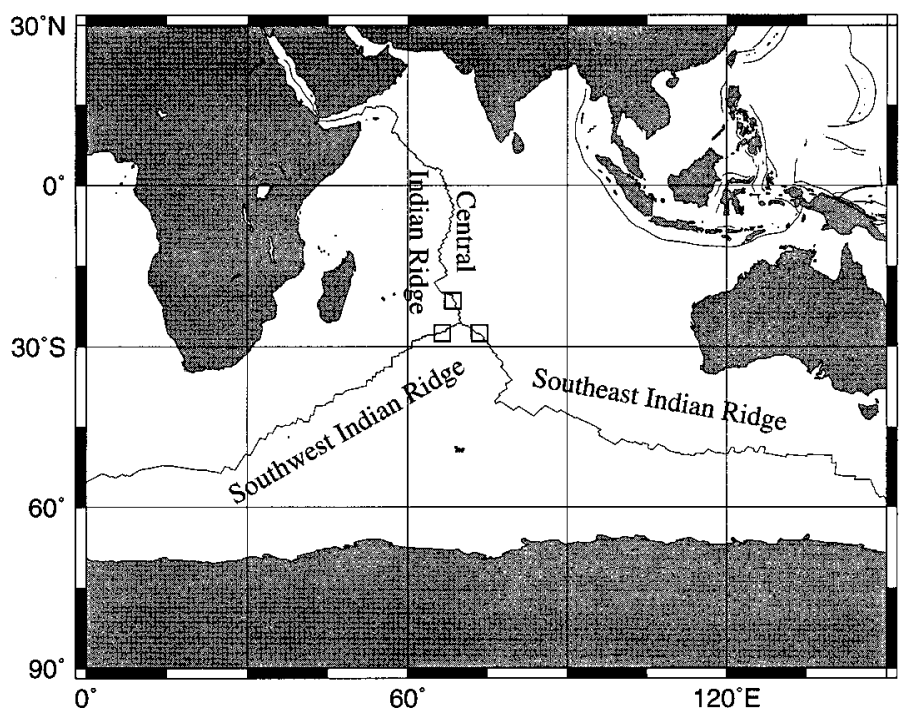

Figure 1. Location map of Indian mid-ocean ridge system showing the three study regions (boxes). 
Figure 2. Bathymetry, free-air gravity anomalies, and mantle Bouguer anomalies (MBAs) from surveys on Southwest Indian Ridge (SWIR), Central Indian Ridge (CIR), and Southeast Indian Ridge (SEIR).

We determined the difference in MBA amplitude from the minimum value within the segment to a distal end and divided the amplitude by the distance to get the gradient. The along-axis gradients at the very slow spreading Southwest Indian Ridge $(0.9 \mathrm{~cm} / \mathrm{yr})$ are $0.4-0.7 \mathrm{mgal} / \mathrm{km}$, similar to gradients found at the slow-spreading Mid-Atlantic Ridge (Lin and Phipps Morgan, 1992). The along-axis MBA gradients at the intermediate-spreading Central Indian Ridge $(2.3 \mathrm{~cm} / \mathrm{yr})$ and Southeast Indian Ridge $(3.1 \mathrm{~cm} / \mathrm{yr})$ are $0.2-0.35$ $\mathrm{mgal} / \mathrm{km}$ (Fig. 3).

The results of this study, combined with published data from the slow-spreading Mid-Atlantic Ridge (Bell and Buck, 1992; Lin and Phipps Morgan, 1992), intermediate-spreading Galapagos Ridge (Ito and Lin, 1994), and fast-spreading East Pacific Rise (Madsen et al., 1990; Wang and Cochran, 1993), show that axial MBA gradients decrease with increasing spreading rate, although with much scatter for half-spreading rates of less than about $2 \mathrm{~cm} / \mathrm{yr}$. For spreading rates above $\sim 3.5 \mathrm{~cm} / \mathrm{yr}$, gradients are constant at about $0.1 \mathrm{mgal} / \mathrm{km}$ (Fig. 3).

Gradients at segments with axial highs are close to $0.1 \mathrm{mgal} / \mathrm{km}$ for the entire range of half-spreading rates from $1 \mathrm{~cm} / \mathrm{yr}$ (Reykjanes Ridge) to over $7 \mathrm{~cm} / \mathrm{yr}$ (southern East Pacific Rise). Gradients at segments with a median valley are quite variable and generally de- 


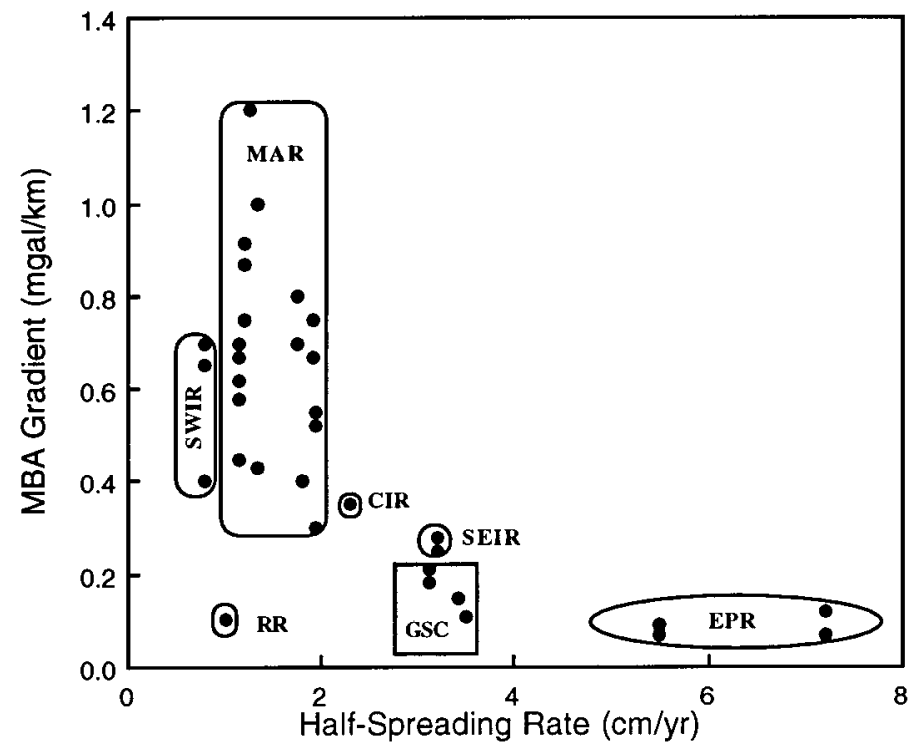

Figure 3. Plot of half-segment MBA gradient against half-spreading rate. GSC-Galapagos spreading center, RR-Reykjanes Ridge, MAR-Mid-Atlantic Ridge, EPR-East Pacific Rise, SWIR-Southwest Indian Ridge, CIR-Central Indian Ridge, SEIR-Southeast Indian Ridge.

crease with increasing spreading rate (Fig. 4A). The same pattern is also present in the variation of across-axis topographic relief with spreading rate (Malinverno, 1993; Small, 1994) (Fig. 4B). The amplitude of axial highs is spreading-rate independent and is limited to a relatively small range over a very wide range $(1-8 \mathrm{~cm} / \mathrm{yr})$ of halfspreading rates. The relief of axial valleys shows a great deal more scatter and decreases with increasing spreading rate (Malinverno, 1993; Small, 1994).

\section{DISCUSSION}

It has been widely assumed that along-axis variations in mantle Bouguer anomalies reflect variations in crustal thickness and that crustal thickness is directly related to the local magma budget from the mantle (e.g., Kuo and Forsyth, 1988; Lin and Phipps Morgan, 1992; Lin et al., 1990). Cooling at slow-spreading ridges occurs rapidly compared to the rate at which material is transported away from the axis. Also, less crustal material is emplaced per unit time, resulting in the release of less latent heat. As a result, relatively low average temperatures beneath the axial region of slow-spreading ridges may preclude along-axis transport of melt, so that melt freezes in place where it ascends. The Mid-Atlantic Ridge segment at $33^{\circ} \mathrm{S}$ exhibits the largest recorded MBA gradient and is associated with large along-axis depth variations so that the axial valley virtually disappears in the center of the segment (Kuo and Forsyth, 1988). A seismic refraction line shot along the axis of the segment shows that the crust is thick in the center of the segment $(\sim 8 \mathrm{~km})$ and thins markedly to $\sim 3.5 \mathrm{~km}$ at the southern end and to $\sim 5.5 \mathrm{~km}$ at the northern end (Tolstoy et al., 1993). If the seismically determined crustal material were distributed equally along the axis, then a crust $\sim 6 \mathrm{~km}$ thick would be generated, which is similar to the observed average crustal thickness. Thus the large systematic along-axis variations in axial depth and gravity anomalies within ridge segments observed along the Mid-Atlantic Ridge (Blackman and Forsyth, 1991; Kuo and Forsyth, 1988; Lin et al., 1990; Morris and Detrick, 1991) probably do reflect variations in crustal thickness resulting from a three-dimensional pattern of mantle upwelling.
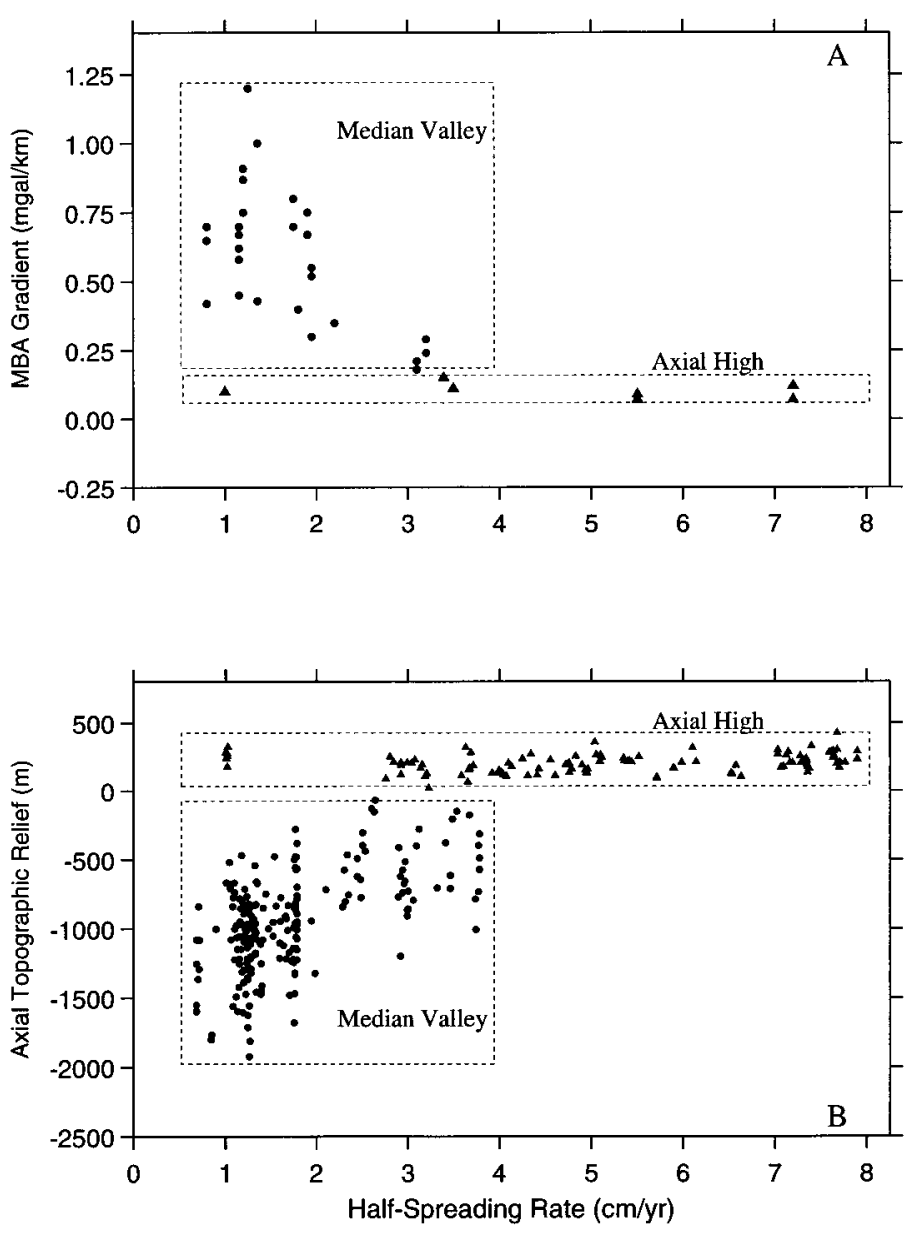

Figure 4. A: Plot of half-segment MBA gradient against half-spreading rate. B: Plot of across-axis bathymetric relief at ridge axis against half-spreading rate.

The effect of temperature on across-axis morphology and along-axis gravity gradients can be observed in the vicinity of hot spots. The Reykjanes Ridge is a slow-spreading ridge under the influence of the Iceland hot spot and subject to mantle temperatures of up to $200{ }^{\circ} \mathrm{C}$ above normal (Cochran and Talwani, 1978). The ridge is shallow, has a thick $(8-10 \mathrm{~km})$ crust, and for a distance of $500 \mathrm{~km}$ away from Iceland is characterized by an axial high rather than an axial valley (Talwani et al., 1971). Bell and Buck (1992) determined that the along-axis MBA anomaly profile of the Reykjanes Ridge is more similar to those observed at the East Pacific Rise than at "normal" sections of the Mid-Atlantic Ridge (see Fig. 3). They suggested that the mantle upwelling is diapiric beneath the Reykjanes Ridge, as at other slow-spreading ridges, but that the thick crust and high temperatures cause the lower crust to be weakened to the extent that it cannot support the stresses resulting from variations in crustal thickness. The lower crust flows under the stress, removing the variations in crustal thickness and resulting in much lower along-axis variations in MBA amplitude.

A similar example of the effect of elevated temperatures on the form of the across-axis morphology and along-axis gravity gradients can be drawn from the intermediate-spreading-rate $(2.2-3.4 \mathrm{~cm} / \mathrm{yr})$ Galapagos spreading center. The spreading center lies about $100 \mathrm{~km}$ north of the Galapagos hot spot at $91^{\circ} \mathrm{W}$. Ito and Lin (1994) argued that mantle temperatures are $65 \pm 30^{\circ} \mathrm{C}$ higher at the part of the ridge axis closest to the hot spot than in distal parts. The ridge axis 
near the hot spot has an axial high and half-segment MBA gradients of about $0.1 \mathrm{mgal} / \mathrm{km}$ (Fig. 3). West of about $95^{\circ} \mathrm{W}$, about $500 \mathrm{~km}$ from the hot spot, the ridge axis is marked by an axial valley. The MBA gradients there are $0.2-0.3 \mathrm{mgal} / \mathrm{km}$ (Fig. 3). These values are less than those observed at slower spreading ridges (Fig. 3). The lower gradients at intermediate-spreading-rate ridges with a rift valley suggest that although some along-axis flow can occur at these spreading rates, the flow is insufficient to completely remove intrasegment crustal-thickness variations. The relief of the axial rift valley at the western Galapagos spreading center is less than about 800 $\mathrm{m}$ and thus is also less than that generally observed at slow-spreading ridges.

We have argued (Wang and Cochran, 1993) from an analysis of gravity and bathymetry data that mantle upwelling is diapiric or focused at the very fast spreading southern East Pacific Rise, where the axis is characterized by an axial high and along-axis MBA gradients of $\sim 0.1 \mathrm{mgal} / \mathrm{km}$. At the $7^{\circ} 12^{\prime} \mathrm{S}-8^{\circ} 38^{\prime} \mathrm{S}$ segment of the southern East Pacific Rise, 50\% more melt must be present in the mantle beneath the center of the segment than at the ends (Wang and Cochran, 1993). This material must be efficiently redistributed along the axis at a relatively shallow level; otherwise, crustal thickness variations similar to those found at the Mid-Atlantic Ridge would result. The along-axis flow may occur either within the crustal magma chamber as suggested by Batiza and Niu (1992) and/or at subcrustal levels so that melt is fed into the magma chamber at locations along the entire length of the ridge segment (Sinton and Detrick, 1992).

\section{CONCLUSIONS}

Along-axis mantle Bouguer half-segment gradients decrease steadily, although with much scatter for half-spreading rates of less than $3.5 \mathrm{~cm} / \mathrm{yr}$. At higher spreading rates, gradients are constant at $\sim 0.1 \mathrm{mgal} / \mathrm{km}$. Along-axis MBA gradients at ridges with an axial high are nearly the same for ridges with half-spreading rates varying from 1 to $7 \mathrm{~cm} / \mathrm{yr}$. We interpret the spreading-rate-independent MBA gradient of $0.1 \mathrm{mgal} / \mathrm{km}$ at ridges with an axial high as the mantle component resulting from lateral density variations due to the focusing of upwelling melt. The higher, but variable, gradients observed at ridges with an axial valley appear to be the result of intrasegment crustal-thickness variations. The decrease in alongaxis MBA gradients with increasing spreading rates at ridges with an axial valley results from an increase in distribution of melt along the axis at crustal and/or subcrustal depths. Along-axis transport of magma is inefficient at ridges with an axial valley, resulting in large crustal thickness variations and large MBA gradients, while efficient along-axis distribution of melt occurs at ridges with an axial high.

The similar relation to spreading rate shown by along-axis gravity gradients and across-axis topographic relief suggests that the same parameters control both. Specifically, the dependence on temperature of the viscosity structure of the mantle and crust appears to control both the across-axis and the along-axis structure. Ridges where along-axis distribution of material is inefficient, so that there are significant intrasegment variations in crustal thickness, are characterized by an axial valley. The lithosphere at ridges where the thermal structure is such that material can be efficiently redistributed along the axis is too weak to support the stress required to maintain an axial valley, and such ridges are characterized by an isostatically compensated axial high.

\section{ACKNOWLEDGMENTS}

Supported by National Science Foundation grants OCE-91-17188 and OCE-93-02091. Alberto Malinverno supplied the data shown in Figure 4B. Roger Buck, Christopher Small, J.-C. Sempere, and John Madsen reviewed the manuscript. Lamont-Doherty contribution 5254.

\section{REFERENCES CITED}

Batiza, R., and Niu, Y., 1992, Petrology and magma chamber processes at the East Pacific Rise $\sim 9^{\circ} 30^{\prime}$ N: Journal of Geophysical Research, v. 97, p. 6779-6797.

Bell, R. E., and Buck, W. R., 1992, Crustal control of ridge segmentation inferred from observations of the Reykjanes Ridge: Nature, v. 357, p. $583-586$.

Blackman, D. K., and Forsyth, D. W., 1991, Isostatic compensation of tectonic features of the Mid-Atlantic Ridge: $25-27^{\circ} \mathrm{S}$ : Journal of Geophysical Research, v. 96, p. 11,741-11,758.

Cochran, J. R., and Talwani, M., 1978, Gravity anomalies, regional elevation and the deep structure of the North Atlantic: Journal of Geophysical Research, v. 83, p. 4907-4924.

Ito, G. T., and Lin, J., 1994, Mantle temperatures along the present and paleo-axes of the Galapagos Spreading Center as inferred from residual gravity analyses: Journal of Geophysical Research, v. 99.

Kuo, B. Y., and Forsyth, D. W., 1988, Gravity anomalies of the ridge-transform system in the south Atlantic between 31 and $34.5^{\circ} \mathrm{S}$ : Upwelling centers and variations in crustal thickness: Marine Geophysical Researches, v. 10 , p. 205-232.

Lin, J., and Phipps Morgan, J., 1992, The spreading rate dependence of three-dimensional mid-ocean ridge gravity structure: Geophysical Research Letters, v. 19, p. 13-16.

Lin, J., Purdy, G. M., Shouten, H., Sempere, J.-C., and Zervas, C., 1990, Evidence from gravity data for focused magmatic accretion along the Mid-Atlantic Ridge: Nature, v. 344, p. 627-632.

Madsen, J. A., Detrick, R. S., Mutter, J. C., Buhl, P., and Orcutt, J. C., 1990 A two- and three-dimensional analysis of gravity anomalies associated with the East Pacific Rise at $9^{\circ} \mathrm{N}$ and $13^{\circ} \mathrm{N}$ : Journal of Geophysical Research, v. 95, p. 4967-4987.

Malinverno, A., 1993, Transition between a valley and a high at the axis of the mid-ocean ridges: Geology, v. 21, p. 639-642.

Morris, E., and Detrick, R. S., 1991, Three-dimensional analysis of gravity anomalies in the Mark area, Mid-Atlantic Ridge, $23^{\circ} \mathrm{N}$ : Journal of Geophysical Research, v. 96, p. 4355-4366.

Munschy, M., 1987, Etude géophysique detailée du Point Triple de Rodriquez et de la zone axiale des Trois Dorsales Associées (Océan Indien) [Ph.D. thesis]: Strasbourg, France, Université Louis Pasteur, 232 p.

Neumann, G. A., and Forsyth, D. W., 1993, The paradox of the axial profile: Isostatic compensation along the axis of the Mid-Atlantic Ridge?: Journal of Geophysical Research, v. 98, p. 17,891-17,910.

Parmentier, E. M., and Phipps Morgan, J., 1990, Spreading rate dependence of three-dimensional structure in oceanic spreading centres: Nature, v. 348 , p. $325-328$.

Sinton, J. M., and Detrick, R. S., 1992, Mid-ocean ridge magma chambers: Journal of Geophysical Research, v. 97, p. 197-216.

Small, C., 1994, A global analysis of mid-ocean ridge axial topography: Geophysical Journal International, v. 116, p. 64-84.

Talwani, M., Windisch, C. C., and Langseth, M. G., 1971, Reykjanes Ridge crest: A detailed geophysical study: Journal of Geophysical Research, v. 76 , p. $473-517$.

Tolstoy, M., Harding, A. J., and Orcutt, J. A., 1993, Crustal thickness on the Mid-Atlantic Ridge: Bull's eye gravity anomalies and focused accretion: Science, v. 262, p. 726-729.

Wang, X., and Cochran, J. R., 1993, Gravity anomalies, isostasy and mantle flow at the East Pacific Rise crest: Journal of Geophysical Research, v. 98 , p. $19,505-19,531$.

Manuscript received June 30, 1994

Revised manuscript received September 12, 1994

Manuscript accepted September 23, 1994 
(A) Bathymetry (m)

\& 8 \& 8 \& 8

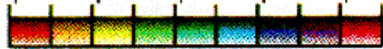

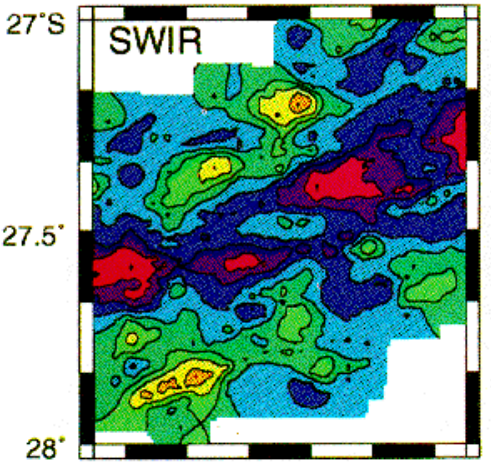

$66^{\circ} \mathrm{E}$

$66.5^{\circ}$

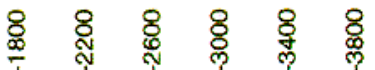

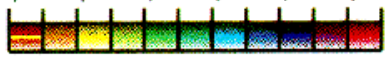

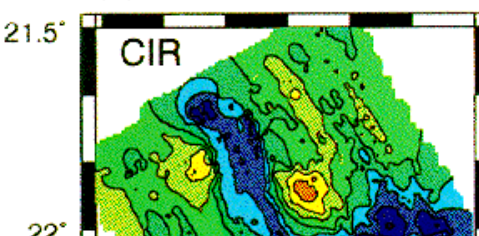

$22^{\circ}$

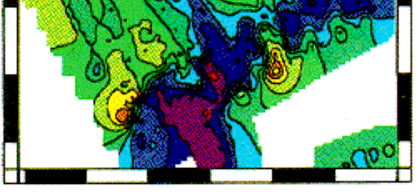

$69^{\circ} \mathrm{E}$

$69.5^{\circ}$

ষิ

\begin{tabular}{|l|l|l|}
\hline & 1 & 1 \\
\hline
\end{tabular}
(B) Free-Air Gravity (mgal)
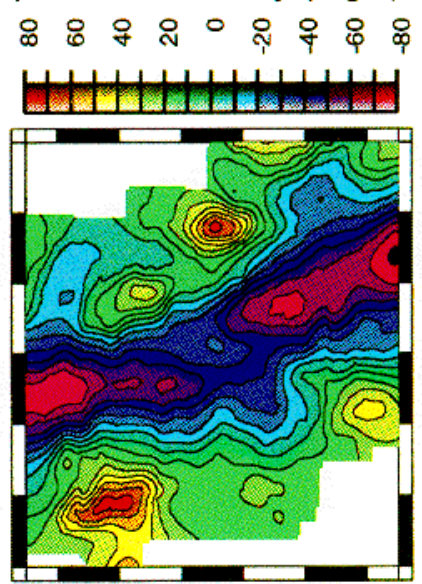

$66^{\circ}$

$66.5^{\circ}$

ㅇำ $\circ$ ำ
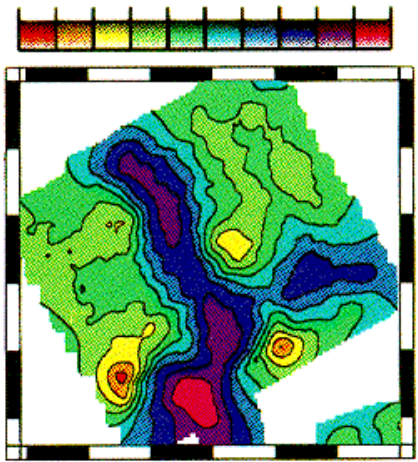

$69^{\circ}$

(C) MBA (mgal)

앙 으으웅 위

W 1 - 1 t

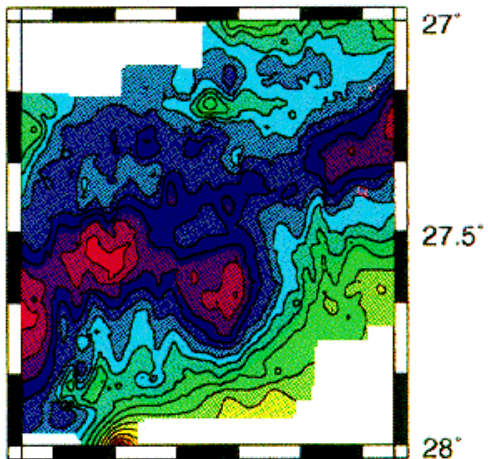

$66^{\circ}$

$66.5^{\circ}$

융ㅇำㅇำ
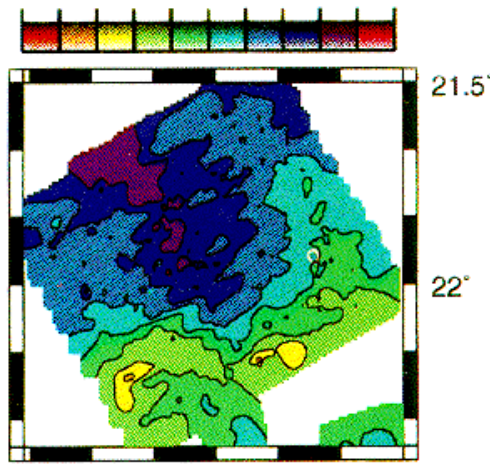

$69^{\circ}$

$69.5^{\circ}$

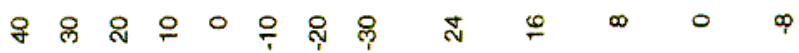

\section{ox}

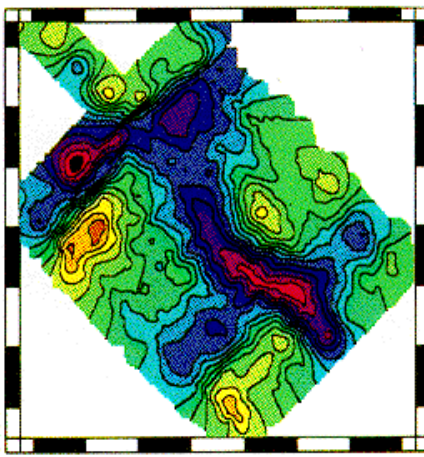

$73.5^{\circ}$

$74^{\circ}$

$73.5^{\circ} \quad 74^{\circ}$

$73.5^{\circ} \quad 74^{\circ}$

$27.5^{\circ}$

28

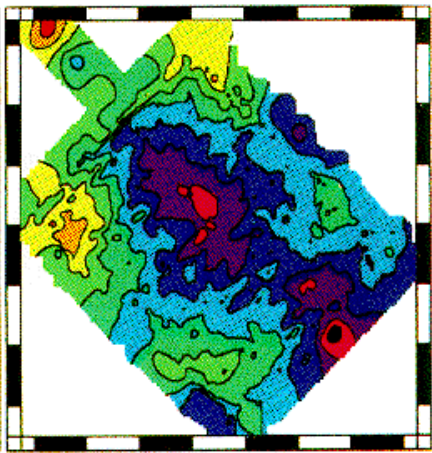

